\title{
USE OF CONDOMS FOR CUSTOMERS OF COMMERCIAL SEX WORKERS IN THE CONTEXT OF HIV / AIDS PREVENTION AT THE BATAM CITY NON-PANTI SOCIAL REHABILITATION CENTER
}

\author{
Indriasari ${ }^{1}$, Ronny Sutanto ${ }^{2}$ \\ indriasari@univbatam.ac.id ${ }^{1}$, ronysutanto@univbatam.ac.id ${ }^{2}$ \\ Medical Education Study Program, Faculty of Medicine, Batam University ${ }^{1}$ \\ Doctor's Professional Study Program, Faculty of Medicine, Batam University ${ }^{2}$ \\ J1. Uniba No. 5, Batam Center
}

\begin{abstract}
Background : AIDS is a disease that is a global health problem after claiming more than 70 million people have been infected with the HIV virus so far. In the city of Batam in 2017, 47 people died from HIV / AIDS. Condom use behavior among sex workers and also customers is one of the efforts to prevent and control the transmission of HIV / AIDS. The purpose of this study was to determine the description of condom use among clients of commercial sex workers in the context of HIV / AIDS prevention.

Method : This research is descriptive conducted at the Center for Social Rehabilitation of Non Panti Teluk Pandan Tanjung Uncang, Batam City, with a total sample of 91 commercial sex worker customers who were taken by purposive sampling.

Result : The results showed. It is known that the use of condoms among CSW customers in the center of the Social Rehabilitation Center for non-Panti Kota Batam, more than half of the customers did not use condoms, namely $46(51.1 \%)$.

conclusion : It is known that the use of condoms among commercial sex workers at the center for nonPanti Panti Social Rehabilitation in Teluk Pandan Tanjung Uncang, Batam City, more than half of the customers did not use condoms, namely 46 (51.1\%).
\end{abstract}

Keywords: HIV / AIDS, Condoms, Sex Workers

\section{INTRODUCTION}

Social deviation can actually be said to be deviant if it occurs in a social situation that is contrary to the principle of this deviation, prostitution is a type of social deviation that has emerged even since ancient Greece, where sex has become a commodity item which at that time was packaged as a package with slavery. however, since slavery was officially abolished, prostitution has become an independent disorder and is often centralized in certain places which are often referred to as lokalisasi (Bakasura, 2017).

Prostitution is a unique issue and quite interesting to discuss because its legal status is not clear until now, but its existence still exists and has received permission from the local government. Localized brothels are protected by the Regional government and the Social Affairs Department, whose security oversight is under the government apparatus, which they allow through procedures determined by the local government. With the localization permit, all forms of implementation and future impacts can be accounted for by the Government (Marzani, 2016).

In Indonesia, some time ago we were enlivened by 2 big issues concerning localization evictions, namely the Dolly 
complex in the Surabaya area and the Kalijodoh Complex in Jakarta. However, the eviction turned out to produce two positive and negative sides, normatively and in social analysis. The eviction of the centralization of localization had a bad impact on ex prostitutes and those involved in it, who then some of them carried out illegal prostitution activities without supervision so that it had a worse impact than before (Bakasura, 2017).

With the development of times and technology of decentralization, this localization then developed a new innovation in the world of prostitution where they (PSK) took advantage of technological developments, especially mobile phones and the internet to run their prostitution business, which then spread widely poison teenagers and men who are looking for decision as the majority of internet users in Indonesia, so that the buying and selling of sexual activities is imitated and becomes a new social deviation in a society that is difficult to control and has the potential to have a tremendous impact on the perpetrator and the environment, and one of the impacts is the increase in disease sexually transmitted disease which is still a big problem for health development (Bakasura, 2017).

Sexually transmitted diseases are pandemics with health, social, economic and political impacts. Sex workers and their clients play an important role in the increase in HIV / AIDS cases in Indonesia, the low bargaining position of women direct sex workers in the use of condoms and risky behavior has made the spread of sexually transmitted diseases (sexually transmitted infections and HIV / AIDS) more widespread (Purnamawati, 2013).

According to the World Health Organization (WHO) HIV continues to be a public health problem globally, after claiming more than 70 million people have been infected with the HIV virus and around 35 million have died so far. In 2015, 1.1 (940 000-1300000) million people have died due to being infected with the HIV virus. There were an estimated 36.7 (34.0-39.8) million people living with HIV at the end of 2016. Globally, Sub-Saharan Africa is the most affected region, with nearly 1 in 25 adults living with HIV ( WHO 2016).

In Indonesia since the beginning of the HIV-AIDS epidemic, nearly 78 million people have been infected with HIV and around 39 million people have died from HIV. In general, 35 million people were living with HIV by the end of 2013 and 1.5 million people died from HIV in 2013, in 2016 there were 41250 people affected by HIV cases and 7491 people in the AIDS stage. The cumulative percentage of AIDS cases based on the most risk factors for transmission through heterosexual relationships (74.0\%), homosexuals (15.8\%), followed by perinatal transmission (3.8\%) and IDU by $2.6 \%$ (Ministry of Health RI, 2017 ).

In some countries, such as in Thailand, HIV / AIDS prevention and control programs that focus on men who have sexual relations with commercial sex workers (CSWs) have shown success in using condoms, known as $100 \%$ compulsory condoms for men. who have sexual relations with prostitutes in prostitution brothels and in embroidery houses (Harahap, 2012). This is not the case in Indonesia as in Thailand. In Thailand, the use of condoms is clearly localized in places of prostitution, while in Indonesia it is not applied to brothels, only the obligation to use condoms as in the existing regional regulations (Purwatiningsih, 2012).

The prevalence of HIV / AIDS in Indonesia in general is still low, but Indonesia has been classified as a country with a concentrated epidemic level, namely where the incidence of HIV / AIDS in general / global is still low but in certain sub-populations the incidence rate is high. Where there is a prevalence of more than $5 \%$ in certain subpopulations, for example commercial sex workers and drug abuse (Narcotics, 
Psychotropics, and other addictive substances), this epidemic level indicates the level of risky behavior that is quite active in transmitting the disease in a certain sub-population. Furthermore, the course of the epidemic will be determined by the number and nature of the relationship between high-risk groups and the general population (Depkes RI, 2007).

In Riau Islands, the number of HIV / AIDS cases reported from 2014-2015 has increased, namely in 2014 new HIV cases amounted to 975 cases, then increased to 1038 cases in 2015. Likewise with AIDS from 2014 as many as 429 cases, an increase to 430 cases in 2015. And there were $1031 \mathrm{HIV}$ shirts and 402 AIDS cases at the end of 2016. The cumulative percentages of AIDS cases based on sex were $52 \%$ male and $48 \%$ female. It can be seen that the detection of HIV cases is more common in men, which is more than $50 \%$ of cases (Riau Islands Health Profile, 2016).

Based on data from the Batam city health office, HIV / AIDS cases have increased significantly until December 2017. Cumulatively from 2011 to 2015 the number of HIV sufferers totaled 2726 people and AIDS cases totaled 1221 This situation continues to increase from time to time. In 2016, there were 694 cases of HIV positive people and 304 people suffering from AIDS. In 2017, there were 768 HIV cases and 270 AIDS cases and 47 people died due to HIV / AIDS (Batam City Health Office Profile 2017).

Narrated that the land in Teluk Pandan was a gift or a grant from the Batam City Social and Cemetery Service (Dinsospam), since 2002. Mayor of Batam Decree Number 6 of 2003 concerning Establishment of Batam City Non-Panti Social Rehabilitation Center. The Teluk Pandan Non-Panti Rehabilitation Center, or better known as the Sintai lokalisasi, was deliberately established by the Batam City Government a few years ago to avoid the practice of prostitution in the middle of the city.
However, the goal is like roasting away from the fire due to the fact that prostitution business continues to flourish throughout Batam, including in downtown Nagoya and Jodoh. The existing data states that in the Sintai brothel there are around 155 sex workers, they work in 24 operating bars, and according to a nongovernmental organization that supplies condoms to Sintai there are still many CSWs who complain because their customers are reluctant to use condoms during sexual intercourse, even though they are condoms. are provided in every bar and pimps are also very supportive of the use of condoms on customers

The use of condoms is a tool that can be used and used by commercial sex workers, both men and women and also by their clients, which functions to prevent or reduce the transmission of several diseases (STDs) caused by sexual intercourse from female partners or on the contrary (Saifuddin, et al 2011). Research Objectives To determine the description of condom use in clients of commercial sex workers in the context of HIV / AIDS prevention.

\section{RESEARCH METHODS}

This research is descriptive. This research was conducted at the Center for Social Rehabilitation of Non Panti Teluk Pandang, Tanjung Uncang, Batam City

\section{RESEARCH RESULT}

Table 1. Frequency Distribution of Respondents based on Condom Use among Customers of Commercial Sex Workers in Non-Orphanage Social Rehabilitation Centers

\begin{tabular}{ccc}
\hline $\begin{array}{c}\text { Use Of } \\
\text { Condoms }\end{array}$ & N & Percentage (\%) \\
\hline $\begin{array}{c}\text { don't use } \\
\text { condoms }\end{array}$ & 44 & 48,9 \\
use condoms & 46 & 51,1 \\
\hline Total & $\mathbf{9 0}$ & $\mathbf{1 0 0}$ \\
\hline
\end{tabular}




\section{DISCUSSION}

This study is different from the research conducted by Indraswari, et al (2016) in Semarang with the title of factors related to risky sexual behavior in truckers with a sample size of 100 people. The following bivariate results are obtained, respondents who have more risky sexual behavior are respondents with married status were already married (45.2\%), compared to unmarried marital status $(0 \%)$. The results of statistical tests using Fisher's Exact test between the variables of the respondent's marital status with risky sexual behavior were obtained $p$ value $=0.020$. From these results it can be concluded that there is a relationship between the respondent's marital status and risky sexual behavior.

Unmarried customers use condoms more than married customers, because they think their life is still long and they do not want to take the risk of being considered stupid by seeking pleasure in a brothel. Meanwhile, married customers are mostly employees in the brothel, they do not use condoms because they are related to their regular partners, they are sure that their partners are not infected with a disease or virus, even though they are sure that they should still take precautions by using condoms, because it does not rule out the possibility. her regular partner is infected by other customers and is not known, such as HIV she will not show signs and symptoms prior to the stage of AIDS.

Customer occupation cannot be used as a benchmark in condom use, because customers with private employment status are more likely to use condoms than self-employed ones. So it is not certain that people who work in private have less income compared to customers who are self-employed, this study is not in accordance with Zacler in Notoatmodjo (2010) argues that the type of work is closely related to the level of income in the work environment, so that the level of income is related to the behavior of respondents in consistency of condom use will have a huge impact.

According to Syukriyya (2011), the higher a person's knowledge of health, the more he will know how to maintain his health. In general, a person's behavior is based on their background, including knowledge of HIV / AIDS. A person with better knowledge of HIV I AIDS and condoms is expected to have a better level of understanding and awareness about HIV / AIDS, and ultimately are expected to have safe sexual behavior so as to avoid HIV / AIDS infection. This is reinforced by the results of the study that some of the factors at the individual level (knowledge, motivation and readiness to use condoms, intention, decision to use condoms, skills and self-efficacy) in adequate situations become factors of consistent condom use (Aditya, 2012). .

This research is strengthened by Kristianti's (2016) research in Kediri with the title predisposing factors and enabling behavior of condom use among wps customers with the following results, the practice of using condoms consistently is mostly carried out on respondents who have good knowledge of STIs and HIV-AIDS, that is, $80.4 \%$. Meanwhile, $80 \%$ of respondents who have less knowledge behave inconsistently in using condoms when having sex in brothels. And most respondents have good knowledge about STIs and HIVAIDS, namely $84.8 \%$ and $15.2 \%$ less knowledgeable. This study is also commensurate with the research conducted by Pradipta (2013) in Bogor with the title factors that affect the consistency of condom use among transgender women with the following results, there is a significant relationship between knowledge and consistency of condom use among waria to prevent HIV / AIDS (Pvalue $=0.02$ ). Where the transgender women who had less knowledge about HIV / AIDS tended to use condoms inconsistently 7 times 
compared to respondents who had good knowledge about HIV / AIDS (OR = 7.0)

The low knowledge of respondents is because there are still many who have not been exposed to information about HIV / AIDS, they mostly get information about HIV / AIDS and condoms on social media so that the level of knowledge is still at the understanding stage has not gone through the application, analysis, synthesis and evaluation stages as previously stated. described by Notoatmodjo (2012). The higher the knowledge, customers tend to consistently use condoms because they already understand how to prevent HIV / AIDS through saving sex, namely by using condoms.

In order to prevent respondents from suffering from STDs again, apart from having to always use condoms in sexual intercourse, it is also necessary to have an examination and treatment for sufferers who have STDs, namely by holding an STD clinic at a health service center in the area. Besides getting treatment at the PMS clinic, it is also necessary to get IEC / counseling either at the localization or individually when the patient comes to the STD clinic.

\section{CONCLUSION}

It is known that the use of condoms among commercial sex workers at the center for nonPanti Panti Social Rehabilitation in Teluk Pandan Tanjung Uncang, Batam City, more than half of the customers did not use condoms, namely $46(51.1 \%)$.

\section{BIBLIOGRAPHY}

Alwi. 2009. Undang-undang pernikahan No 1 tahun $1974 \quad$ (online) http://malwi.com/undang-undang-perkawinan-no1-tahun-1974.html,,. diakses tanggal 8 juli 2018

Andhyantoro Iwan, Kumalasari Intan, 2012. Kesehatan Reproduksi, Jakarta : Salemba Medika
Anggi (2015) Hubungan pengetahuan ibu hamil tentang perkembangan janin dengan sikap ibu hamil terhadap perkembangan janin. Karya tulis ilmiah tidak diterbitkan. Universitas Batam. Kepulauan Riau

Anjani, A. D., \& Zahara, D. (2020). KEJADIAN YANG MEMPENGARUHI REMAJA LAKI-LAKI DALAM MELAKUKAN MASTURBASI. Jurnal Kebidanan Malahayati, 6(2), 222-229

Aulia, Devy lestari Nurul (2016). Pengaruh Pemberian Informasi Terhadap Peningkatan Pengetahuan Pekerja Seks Komersial Tentang Pemeriksaan Inspeksi Visual Asam Asetat (Iva). Jurnal Kebidanan Malahayati 2(3)

Bakasuracendekia. 2017. " penyebab dan dampak prostitusi online”, (online), (http://bakasurace.ndekia.blogspot.co.id/ „. Diakses tanggal 27 Maret 2018

Dinkes Kota Batam, 2017. Profil kesehatan kota Batam, Dinkes Batam

Imran, 2014. Metodologi penelitian bidang kesehatan, Jakarta : CV Sagung Seto

Kementrian kesehatan RI, 2014. Pedoman Penerapan Terapi HIV Pada Anak. Jakarta.

Kristianti (2016) faktor predisposisi dan pemungkin perilaku penggunaan kondom pada pelanggan wps di semampir kediri. Skripsi tidak diterbitkan. Poltekkes Kemenkes Malang

Kurniasari (2017) Hubungan Antara Tingkat Pendidikan, Pekerjaan dan Pendapatan Orang Tua Dengan Status Gizi Pada Siswa SD Hangtuah 6 Surabaya. Skripsi tidak diterbitkan. Universitas Negeri Surabaya

Lina (2016) Faktor-faktor yang berhubungan dengan perilaku seksual beresiko pada trucker di pelabuhan Semarang. Skripsi tidak di terbitkan. Universitas Di Ponogoro Semarang

Maria (2015) Beberapa faktor resiko yang berpengaruh terhadap kejadian HIV/AIDS pada lelaki umur 25-44 tahun di kota Dili Timor Leste. Tesis tidak di 
terbitkan. Universitas Di Ponogoro Semarang

Marzani (2016) Dampak panti rehabilitasi pekerja seks komersial (PSK) terhadap masyarakat (Studi kasus di Sintai Kec. Batu Aji-Batam Tahun 2013-2014). Skripsi tidak di terbitkan. Universitas kepulauan Riau

$P 2 P l$, 2017. Data Kasus HIV/AIDS di kota Batam. Dinas Kesehatan Kota Batam

Mardhiah, A., \& Anjani, A. D. (2020). HUBUNGAN PENGGUNAAN KONTRASEPSI HORMONAL DENGAN KEJADIAN KANKER PAYUDARA DI RSUD EMBUNG FATIMAH KOTA BATAM TAHUN 2017. Zona Kebidanan: Program Studi Kebidanan Universitas Batam, 9(2)

Purwatiningsih (2012). Faktor-faktor yang berhubungan dengan perilaku penggunaan kondom pada pelanggan pekerja seks komersial dalam rangka pencegahan HIV/AIDS di lokalisasi Kampung Baru. Skripsi tidak di terbitkan. Universitas Indonesia

Purwoastuti, Walyani, 2015. Komonikasi dan Konseling Kebidanan, Yogyakarta : Pustakabarupress

Puspita (2016) Pengaruh Pendekatan blended laerning terhadap pengetahuan dan siswa SMA Negeri Semarang tentang infeksi menular seksual. Karya Tulis Ilmiah tidak di terbitkan. Universitas Diponogoro Semarang.

Puspita (2016) Perbedaan tindakan penggunaan kondom pada wanita pekerja seks langsung dan tidak langsung dalam pencegahan HIV/AIDS di Sidoarjo. Jurnal berkala. Universitas Airlangga Surabaya

Rumengan, dkk, 2015. Metode Penelitian Kuantitatif, Medan : Perdana Publishing

Saifuddin, dkk, 2011. Buku Panduan pelayanan kontrasepsi, Jakarta : Yayasan Bina Pustaka Sarwono Prawiharjo

Saptabakti. 2016. "perilaku pencegahan penyakit menular seksual di kalangan wanita pekerja seksual langsung”, (online), (http://akkes.saptabakti.ac.id/,,. Diakses tanggal 27 Maret 2018
Setyoadi, Triyanto Endang, 2012 Strategi Pelayanan Keperawatan Bagi Penderita AIDS, Graha Ilmu.Sianturi (2012) Hubungan faktor perdisposisi, pendukung dan penguat dengan tindakan penggunaan kondom pada WPS untuk pencegahan HIV/AIDS di Kabupaten serdang Bedagai. Thesis tidak di terbitkan. Universitas Sumatra Utara.

Susanti (2014) Perilaku penggunaan kondompada komonitas LSL di Medan. Skripsi tidak diterbitkan. Universitas Sumatra Utara

Vera (2015) Hubungan dukungna sosial keluarga dengan tingkat depresi pada pasien HIV/AIDS(ODHA) Di rumah Sakit Kemuliaan. Skripsi tidak di terbitkan. Universitas Batam. Kepulauan Riau.

dinkesriau.net/downlot.php?...Profil\%20Kesehx atan\%20Provinsi\%20Riau\%20Tahun\% 2015.Diakses tanggal 18 Maret 2017

http://eprints.undip.ac.id/53792/3/Ike_Mega_Pu spita 22010112130092 BAB II.pdf. Diakses tanggal 15 Maret 2018

http://indraallen.blogspot.com/2013/11/faktorfaktor-pembentuk perilaku.html. Diakses tanggal 8 Juli 2018

https://media.neliti.com/media/publications/195 269-ID-analisis-faktor-yangberhubungan-dengan.pdf. Diakses tanggal 15 Maret 2018

https://media.neliti.com/media/publications/137 915-ID-faktor-faktor-yangberhubungan-dengan-pr.pdf. Diakses tanggal 28 Agustus 2018

http://www.inews.id/daerah/jatim/nekat-praktikprostitusi-di-dolly-2-germo-dan-3-pskditangkap. Diakses tanggal 27 Maret 2018

http://www.depkes.go.id/resources/download/pu sdatin/profil-kesehatan indonesia/profilkesehatan-Indonesia-2015. Diakses tanggal 11 Maret 2017

https://yhantiaritra.wordpress.com/2015/06/03/ kategori-umur-menurut-depkes 2009. Diakses tanggal 27 Maret 2018 